ISSN : $2620-4665$ (print)

ISSN : $2620-4673$ (online)

Website : http://jurnal.untan.ac.id/index.php/JPLP2KM

\title{
ANALISIS PELAKSANAAN PELAYANAN KESEHATAN REMAJA PADA SMA MUHAMMADIYAH 1 PONTIANAK
}

\author{
Tri Atika Febriany \\ Fakultas Hukum, Universitas Muhammadiyah Pontianak \\ Email: atika@unmuhpnk.ac.id
}

\begin{abstract}
ABSTRAK
Masa remaja merupakan masa transisi dari masa kanak-kanak menuju dewasa, yang ditandai dengan timbulnya keinginan kebebasan dalam mencari jati diri. Kebebasan dan keinginan tersebut mendorong para remaja untuk melakukan hal-hal baru, termasuk melakukan hal yang dapat menimbulkan dampak kesehatan yang negatif bagi dirinya, salah satunya ialah perilaku seks pranikah. Pada masa remaja terjadi perubahan-perubahan terhadao fisik, emosi, maupun psikologis termasuk kognitif. Perubahan biologis, psikologis dan sosial terjadi pada masa transisi remaja dari anak-anak ke dewasa, yang secara menyeluruh dapat menjadi masalah bagi remaja. Banyaknya permasalahan yang muncul pada masa remaja, sehingga memerlukan suatu layanan kesehatan bagi remaja yang memadai. Saat ini pelayanan kesehatan untuk remaja dirasa masih belum optimal, melalui program berbasis kesehatan dan konseling remaja, oleh karena itu Muhammadiyah dan Nasyiatul Aisyiyah Kota Pontianak melakukan kegiatan Pelayanan Kesehatan Remaja Milik Nasyiatul Aisyiyah (PASHMINA). Kegiatan ini merupakan salah satu solusi yang diberikan dengan harapan dapat mencegah dan mengatasi kasus kekerasan seksual pada perempuan dan anak.
\end{abstract}

\section{Keywords: PHASMINA, Remaja, Pelayanan Kesehatan}

\section{PENDAHULUAN}

Masa remaja merupakan masa transisi dari masa kanak-kanak menuju dewasa, yang ditandai dengan timbulnya keinginan kebebasan dalam mencari jati diri. Kebebasan dan keinginan tersebut mendorong remaja untuk melakukan hal yang baru, termasuk melakukan hal yang dapat menimbulkan dampak kesehatan yang negatif bagi dirinya, misalnya perilaku seks pranikah (Papathanasiou \& Lahana, 2005; Santrock, 2012; Tomasik \& Silbereisen, 2005).

Pada masa remaja terjadi perubahan-perubahan fisik, emosi, maupun psikologis termasuk kognitif (Papathanasiou \& Lahana, 2005; Santrock, 2012; Scherf et al., 2012). Dalam masa ini, terjadi perubahan fisik yang sangat cepat, namun perubahan tersebut seringkali tidak sejalan dengan perkembangan psikologis, sehingga mempengaruhi kemampuan pengambilan keputusan 
remaja, termasuk melakukan tindakan berisiko (Santrock, 2012). Hal ini terjadi karena adanya rasa ingin tahu yang besar, dan keinginan untuk mencoba sesuatu hal yang baru termasuk perilaku berisiko. Oleh karena itu, periode remaja merupakan masa yang rentan dalam perkembangannya.

Perubahan biologis, psikologis dan sosial terjadi pada masa transisi remaja dari anak-anak ke dewasa, yang secara menyeluruh dapat menjadi masalah bagi remaja (Scherf et al.,2012) .Stres perubahan dapat dialami remaja jika mereka kurang memiliki kemampuan yang matang dalam mengatasi perubahan ini. Stres perubahan ini cenderung mempunyai dampak pada hubungan keluarga, tetapi kebanyakan tidak menimbulkan kecenderungan penyebab berkembangnya masalah keluarga yang serius (Walsh and Scheinkman, 1993, cit. Howell, 2001). Tahapan perubahan yang terjadi pada masa remaja tidak bisa diartikan universal. Secara konteks, hubungan dengan keluarga cukup penting menentukan pengalaman remaja selama tahap perubahan ini.

Hasil penelitian sebelumnya menunjukkan bahwa 14,7\% remaja SMA di Kota Pontianak mengaku pernah melakukan hubungan seks pranikah (Suwarni, 2009). Sejalan dengan penelitian yang dilakukan Suwarni dan Selviana (2015) pada remaja SMP dan SMA di Kota Pontianak menunjukkan bahwa inisiasi seks pranikah remaja diawali dengan pegangan tangan $(82,7 \%)$, berpelukan $(60,7 \%)$, cium pipi $(66 \%)$, meraba daerah sensi-tive $(19,3 \%)$, seks oral $(7 \%)$, seks anal $(4 \%)$, dan intercourse $(14,7 \%)$. Selain itu, yang menjadi salah satu penyebab yang mengarahkan pada perilaku tersebut adalah paparan pornografi.

Banyak permasalahan yang muncul pada masa remaja, sehingga memerlukan layanan kesehatan remaja yang memadai. Saat ini pelayanan kesehatan untuk remaja masih belum optimal, sehingga Muhammadiyah melalui Nasyiatul Aisyiyah Kota Pontianak mencoba memulai program berbasis kesehatan dan konseling remaja, yaitu Pelayanan Remaja Sehat Milik Nasyiatul Aisyiyah, atau yang lebih dikenal dengan PASHMINA. PASHMINA merupakan salah satu bentuk solusi yang ditawarkan untuk dapat mencegah serta mengatasi kasus kekerasan seksual pada perempuan dan anak. PASHMINA merupakan wadah berkumpulnya para remaja dalam mengembangkan diri, bertukar pikiran tentang kesehatan dan kesehatan reproduksi, konsultasi psikologi yang terdiri atas pos layanan kesehatan meliputi layanan indeks masa tubuh dan pemeriksaan kadar Hemoglobin (HB), pos konsultasi kesehatan reproduksi, pos konseling dan pos makanan bergizi serta pos edukasi. Dakwah Nasyiatul Aisyiyah melalui PASHMINA ini 
ISSN : $2620-4665$ (print)

ISSN : $2620-4673$ (online)

Website : http://jurnal.untan.ac.id/index.php/JPLP2KM

diharapkan dapat menciptakan remaja sehat, unggul, dan berakhlak mulia dalam rangka mewujudkan masyarakat islam yang sebenar-benarnya.

Kegiatan PASHMINA merupakan kegiatan yang dikembangkan saat Muktamar XIII Nasyiatul Aisyiyah yang dilaksanakan di Universitas Muhammadiyah Yogyakarta tanggal 26-28 Agustus 2016. Pada awalnya PASHMINA diinisiasi oleh Bidang Dakwah Pengurus Daerah Nasyiatul Aisyiyah Kota Yogyakarta periode 2008-2012, pada tahun 2009. Sebelum dilaksanakan di Kota Pontianak, PASHMINA telah dilaksanakan oleh Nasyiatul Aisyiyah Kota Yogyakarta, Kabupaten Lamongan dan Lebak Banten. Kegiatan PASHMINA belum pernah dilaksanakan di Kalimantan Barat, khususnya di Kota Pontianak. Oleh karena itu PDNA Kota Pontianak, membentuk PASHMINA di Kota Pontianak.

Melihat permasalahan yang terjadi pada remaja di kota pontianak, seperti status gizi remaja, maraknya penyalahgunaan Narkoba, perilaku pacaran yang mengarah pada seks pranikah, dan lain sebagainya, memerlukan upaya penanganan dalam rangka mencegah dan mengatasi permasalahan tersebut. Salah satu upaya yang dapat dilakukan, yaitu membentuk PASHMINA di

Kota Pontianak. PASHMINA akan dilaunching pertama kali di SMA Muhammadiyah 1 Pontianak dan akan berlangsung rutin setiap 2 bulan di sekolah SMP, SMA, dan SMK Muhammadiyah SeKota Pontianak. Kami juga akan mengadakan seminar Motivasi untuk Remaja yang akan di akhir kegiatan Pashmina. Selain itu, program dakwah ini bisa diintegrasikan melalui mata pelajaran kemuhammadiyahan, kami mengharapkan dengan adanya kegatan ini dapat membentuk generasi penerus bangsa yang sehat, unggul, dan berakhlak mulia.

\section{METODE PELAKSANAAN KEGIATAN}

\subsection{Waktu dan Tempat}

Kegiatan PASHMINA dilaksanakan pada hari Sabtu, tanggal 24 Februari 2018, bertempat di SMA MUHAMMADIYAH 1 Kota Pontianak, yang berkedudukan di Jalan Parit H. Husin II, Bansir Darat, Kecamatan Pontianak Tenggara, Kota Pontianak. Agenda kegiatan ialah memperkenalkan PASHMINA di Kota Pontianak, melakukan Penyuluhan dan Pemeriksaan Kesehatan. 


\subsection{Prosedur Kegiatan}

Prosedur yang dilakukan pertama kali adalah menentukan target lokasi kegiatan yaitu SMA (Sekolah Menengah Atas) yang notabene adalah para siswa/i atau remaja. Berdasarkan target kegiatan yang direncanakan, maka kegiatan Pengabdian Kepada Masyarakat yang dirasa tepat sasaran adalah Pelayanan kesehatan di lingkungan siswa/i SMA di Kota Pontianak, Kalimantan Barat. Dengan proposisi bahwa sebelum melakukan pelayanan kesehatan (dalam bentuk penyuluhan) di luar dari Persyarikatan Muhammadiyah, maka beban dan kewajiban untuk melangsungkan penyuluhan terlebih dahulu di kalangan internal Muhammadiyah dirasa sangat penting. Untuk kalangan generasi muda, maka sudah tepat dilakukan di SMA Muhammadiyah 1 Pontianak yang merupakan calon generasi penerus bangsa yang diharapkan punya pola hidup sehat dan seimbang.

Target peserta yang diharapkan dapat mengikuti kegiatan penyuluhan ini adalah 50 sampai dengan 100 orang siswa/i. Selanjutnya melakukan koordinasi dengan pihak otoritas sekolah terkait kesiapan penyelenggaraan kegiatan, berserta dengan konfirmasi surat tugas yang sudah dibuat oleh Pimpinan Daerah Nasyiatul Aisyiyah. Setelah melakukan koordinasi dengan pihak sekolah, maka selanjutnya mempersiapkan ruang atau tempat penyuluhan dilakukan, berikut dengan prosedur peminjaman sebagian perlengkapan milik sekolah. Ruang atau tempat penyuluhan dilakukan adalah Aula dan ruangan laboratorium milik SMA Muhammadiyah 1 Pontianak dengan kapasitas 50 sampai dengan 100 orang. Sarana dan prasarana yang dipersiapkan adalah backdrop, banner, meja, kursi, infokus dan layar infokus, microphone, speaker, daftar hadir, alat cek kesehatan berupa pengukur tensi darah, alat cek mata, alat timbang berat badan dan dokumen pelengkap lainnya. Kemudian dilakukan penyusunan materi dan/atau kartu pemeriksaan kesehatan yang dibagikan kepada setiap peserta.

\subsection{Metode Kegiatan}

Metode kegiatan pengabdian dilakukan dalam bentuk penyuluhan dan pemeriksaan kesehatan kepada para siswa/siswi di SMA Muhammadiyah 1 Pontianak. Penyuluhan kesehatan remaja dipandu oleh 2 (dua) orang narasumber dan moderator. Adapun peserta kegiatan terdiri dari siswa/siswi SMA Muhammadiyah 1 Pontianak yang didampingi oleh Guru. Pemeriksaan Kesehatan diawali Pengukuran masa tubuh, indeks lemak tubuh, tekanan darah dan pemeriksaan mata kemudian dilanjutkan dengan pengetahuan mengenai Reproduksi bagi remaja yang 
ISSN : $2620-4665$ (print)

ISSN : $2620-4673$ (online)

Website : http://jurnal.untan.ac.id/index.php/JPLP2KM

diuraikan oleh narasumber. Kemudian dilanjutkan dengan pengenalan dan klinik psikologi remaja. Kegiatan penyuluhan Pashmina ini dilakukan dalam 2 (dua) sesi dengan 2 narasumber, yaitu sesi pertama fokus dalam memberikan pemaparan informasi tentang talk show reproduksi dilanjutkan dengan pemeriksaan kesehatan. Pada sesi kedua, dibuat Klinik Psikologi Remaja diakhiri dengan pemberian bermain game pengenalan psikologi bagi remaja untuk mengetahui dan mengevaluasi seberapa jauh pemahaman siswa/siswi mengenai pemaparan yang telah narasumber berikan.

\section{HASIL DAN PEMBAHASAN}

\subsection{Persiapan Kegiatan}

Persiapan dilakukan beberapa bulan sebelum hari pelaksanaan. Dengan dibantu oleh pihak sekolah dan Nasyiatul Aisyiyah Kota Pontianak. Persiapan yang dilakukan antara lain pengurusan peminjaman alat-alat kesehatan kepada STIK Muhammadiyah beserta mahasiswa STIK yang membantu melakukan pemeriksaan maupun kepada sponsor yang membantu dalam pemeriksaan kesehatan mata. Tepat satu hari sebelum hari pelaksanaan dilakukan pemasangan spanduk, backdrop, sound system (microphone dan speaker), pemasangan infokus dan layar infokus, dan/atau menata letak isi ruangan dengan alat perlengkapan. Kemudian mempersiapkan kartu kesehatan yang akan diberikan pada saat kegiatan berlangsung, dan mempersiapkan konsumsi yang akan diberikan kepada peserta (siswa/siswi) penyuluhan. Tidak ada kendala yang berarti dalam persiapan kegiatan yang dilakukan.

\subsection{Pelaksanaan Kegiatan}

Kegiatan Pelayanan Kesehatan Milik Nasyiatul Aisyiyah (Pashmina) merupakan agenda yang dilakukan oleh Nasyiatul Aisyiyah Kota Pontianak, yang mana dalam hal ini merupakan bagian dari Pengabdian Kepada Masyarakat (PKM) Nasyiatul Aisyiyah (NA) Kota Pontianak. Rangkaian kegiatan pengabdian dilakukan selama satu hari dimulai pukul 07.00 WIB hingg pukul 12.00 WIB, pada tanggal 24 Februari 2017. Pelaksanaan kegiatan diawali dengan proses registrasi peserta pada pukul 07.00 WIB. Peserta yang melakukan registrasi berjumlah 100 orang siswa/i.

Setelah registrasi dilakukan seluruh peserta masuk ke dalam ruangan, kemudian dilanjutkan dengan pembukaan kegiatan yang bertempat di Aula SMA Muhamadiyah 1 Pontianak. Pembukaan kegiatan berlangsung khidmat dan dibuka oleh MC (Anggota Nasyiatul Aisyiyah) diawali dengan menyanyikan lagu Indonesia Raya dan Mars Muhammadiyah. Kemudian acara dibuka dengan kata sambutan oleh Ketua PD Nasyiatu Aisyiyah Kota Pontianak, Kepala Sekolah SMA Muhammadiyah 
1 Pontianak yang didampingi oleh Wakil Kepala Sekolah yang juga membidangi hubungan masyarakat, dilanjutkan dengan kata sambutan oleh Ketua PDM Kota Pontianak sekaligus membuka acara Pashmina.

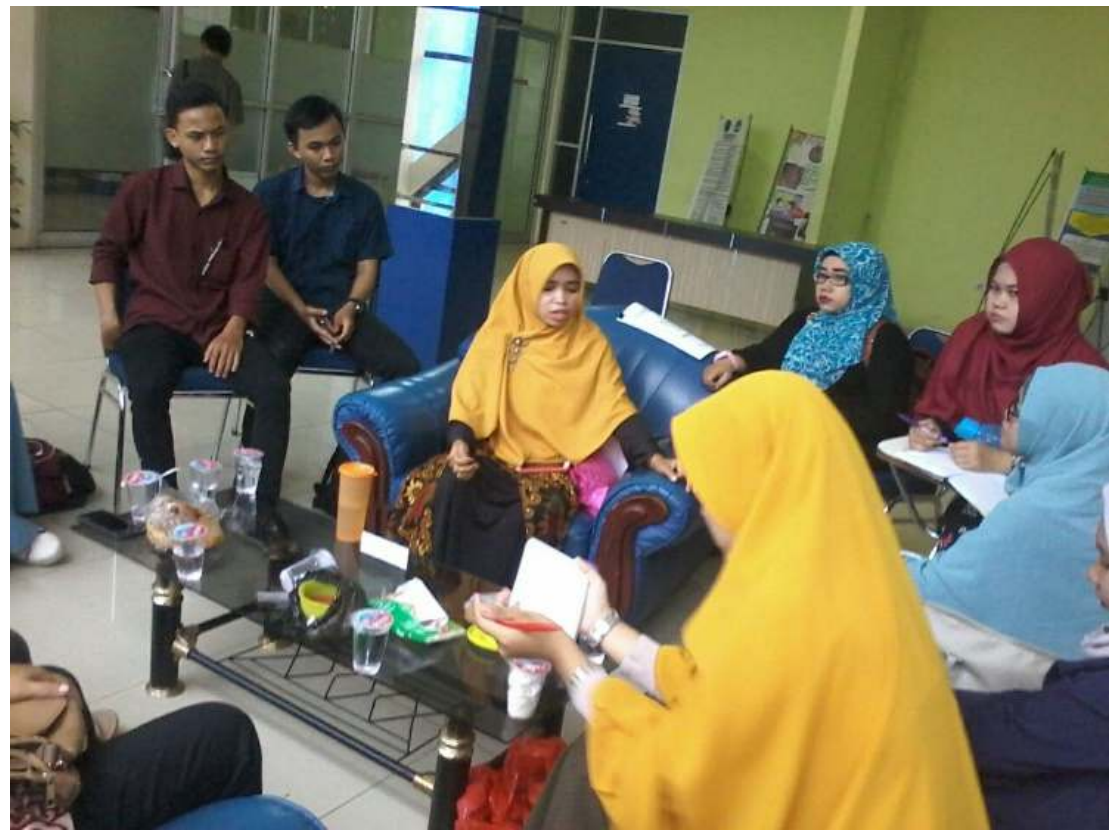

Gambar 1. Rapat Persiapan Kegiatan

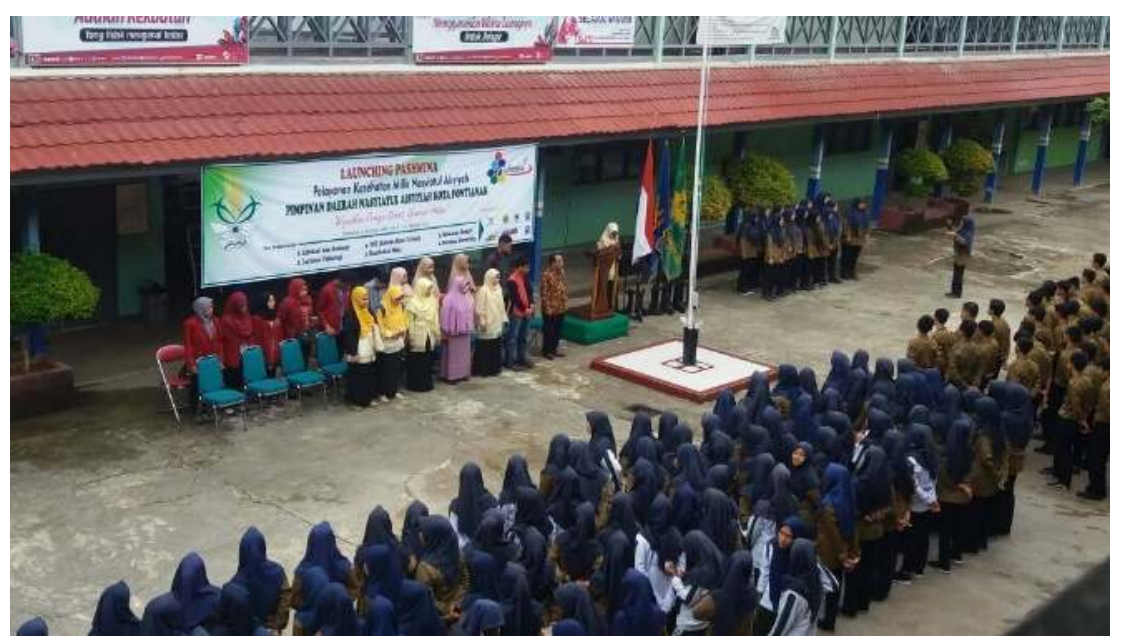

Gambar 2. Upacara Pembukaan Kegiatan 
ISSN : $2620-4665$ (print)

ISSN : 2620 - 4673 (online)

Website : http://jurnal.untan.ac.id/index.php/JPLP2KM

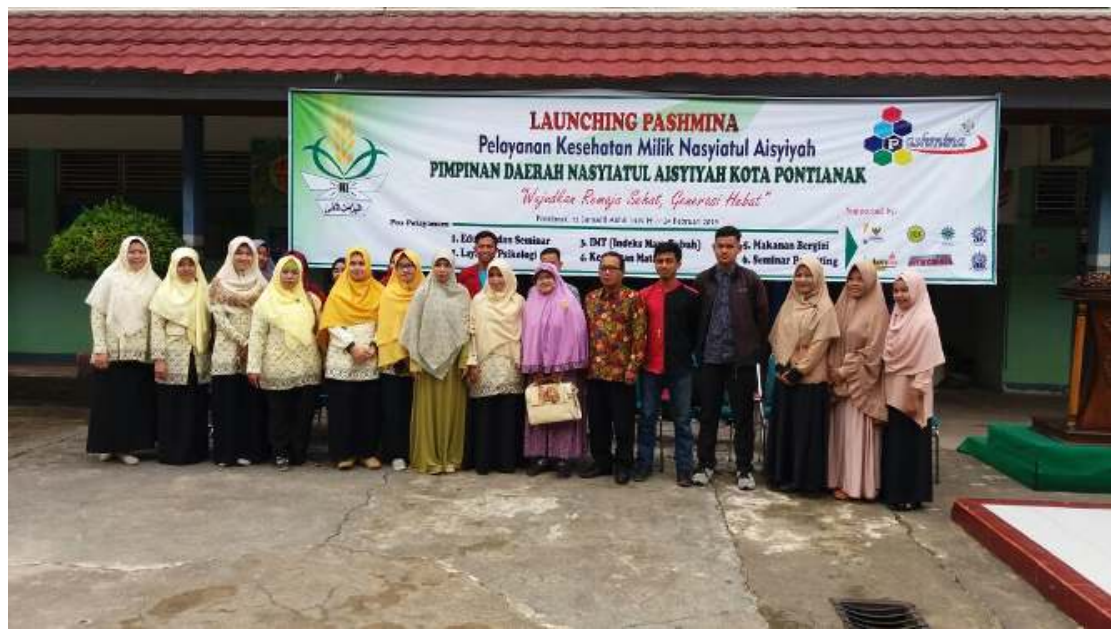

Gambar 3. Launching Pashmina di SMA Muhammadiyah 1 Pontianak

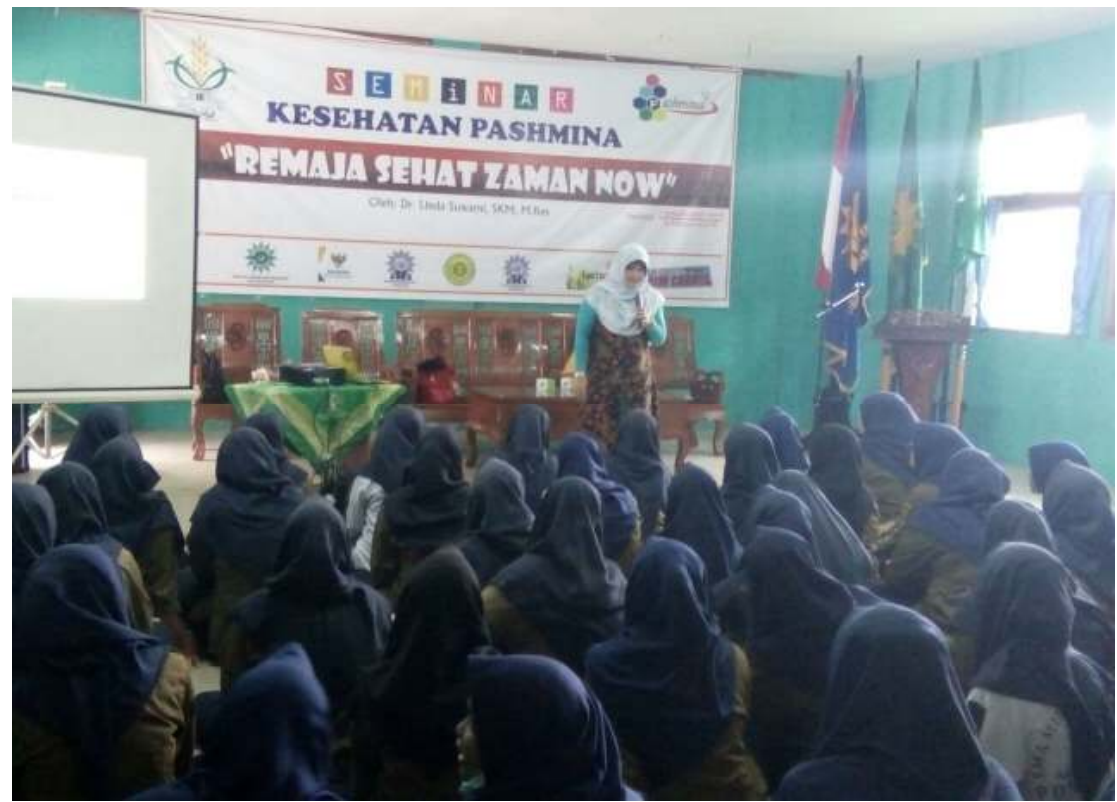

Gambar 4. Seminar Kesehatan Reproduksi yang disampaikan oleh Narasumber 

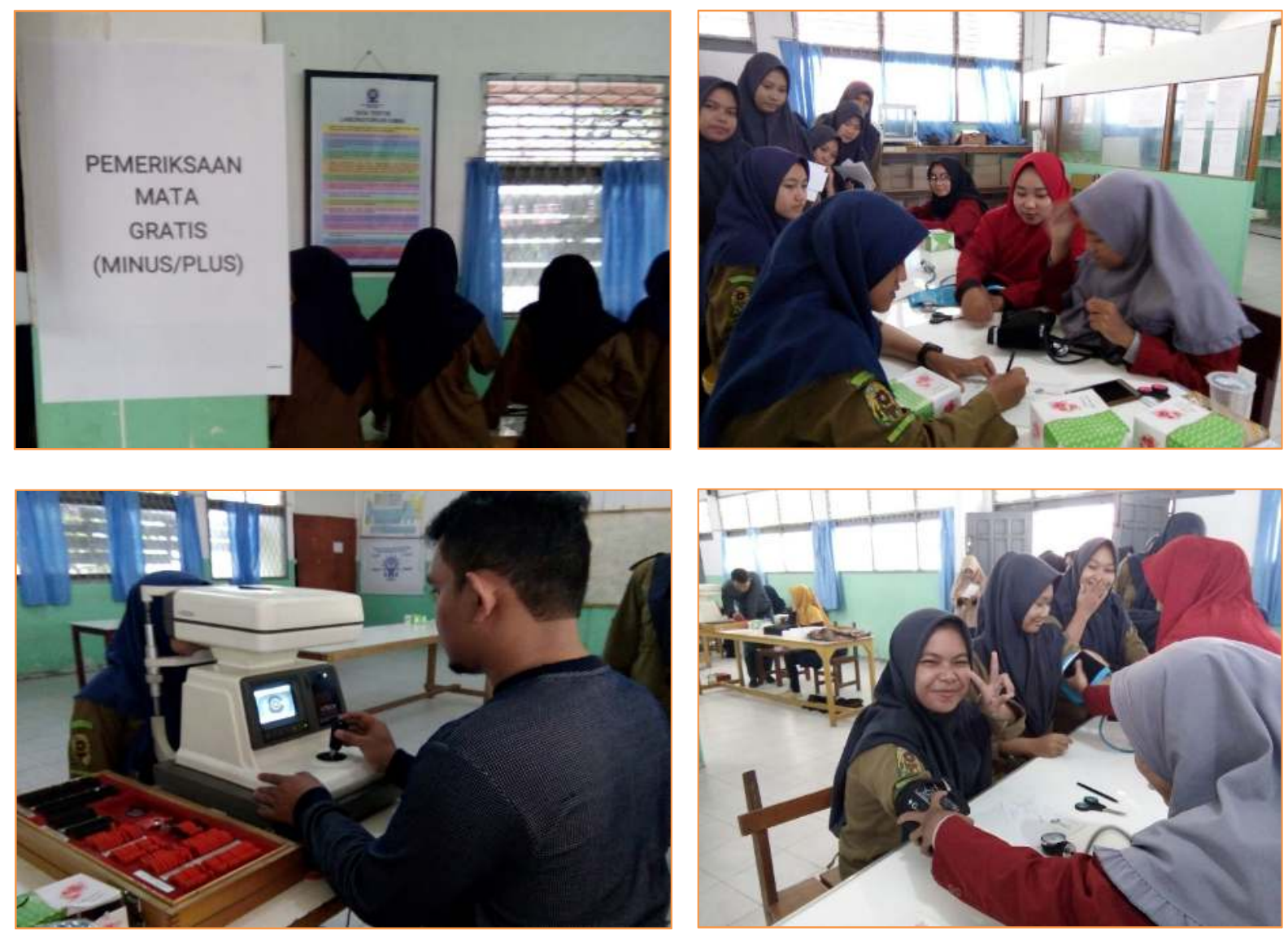

Gambar 5. Kegiatan Pemeriksaan Kesehatan siswa/iSMA Muhammadiyah 1 Pontianak.

Kemudian setelah selesai agenda pembukaan, kegiatan dilanjutkan dengan talk show tentang kesehatan reproduksi remaja. Selanjutnya diuraikan oleh Narasumber 1 dan dilanjutkan dengan pemeriksaan kesehatan remaja yang dilakukan di ruang laboratorium SMA 1 Muhammadiyah Pontianak. Setelah pemeriksaan keehatan selesai siswa/siswi (peserta) Pashmina diberikan kartu hasil pemeriksaan kesehatan mereka, untuk kemudian dapat melanjutkan mengikuti rangkaian acara berikutnya yaitu Klinik Psikologi Remaja yang kembali kegiatan dilakukan di ruang aula SMA 1 Muhammadiyah di pandu oleh para Psikolog yaitu dosendosen Program Studi Psikologi Universitas Muhammadiyah Pontianak, diakhiri dengan game untuk menyegarkan suasana dan membantu melihat pemahaman peserta Pashmina terhadap materi yang disampaikan narasumber. 
ISSN : $2620-4665$ (print)

ISSN : $2620-4673$ (online)

Website : http://jurnal.untan.ac.id/index.php/JPLP2KM

\section{KESIMPULAN DAN SARAN}

\section{KESIMPULAN}

Dari seluruh rangkaian kegiatan ini, maka dapat ditarik kesimpulan bahwa Pemeriksaan Kesehatan ini amat penting untuk generasi muda di Indonesia. Dalam rangka memberi kesadaran kepada remaja pentingnya kesehatan fisik dan psikologis maka pemeriksaan kesehatan sejak dini adalah merupakan tugas krusial para civitas akademika sebagai bentuk pengabdian kepada masyarakat, bangsa, dan Negara. Melalui penyuluhan kesehatan remaja, para generasi muda (siswa atau pelajar). Pre Test dan Post Test mengenai kesehatan reproduksi remaja, dan hasil akhir pemeriksaan kesehatan remaja baik secara fisik dan konsultasi psikolog sebagai evaluasi dan indikator keberhasilan maka dapat dinilai bahwa peserta mampu untuk membedakan mana perbuatan yang masuk kategori membahayakan kesehatan dan mana yang tidak. Peserta juga cukup mampu untuk mengetahui tentang faktor-faktor apa saja seseorang yang mempengaruhi prilaku kesehetan reproduksi remaja, dan moralitas seorang manusia dalam kehidupan di masyarakat.

\section{SARAN}

Pemerintah perlu melakukan pemeriksaan kesehatan secara intensif secara merata di semua kota dan/atau sekolah atau di lingkungan pemuda. Mengagendakan pemeriksaan rutin terhadap remaja di kota Pontianak dengan kunjungan ke sekolah-sekolah yang ada di wilayah kota pontianak

\section{DAFTAR PUSTAKA}

Santrock, John W. 2012. Life-span Development. 13 ${ }^{\text {TH }}$ Edition. University of Texas, Dallas : Mc Graw-Hill

Santrock, John W. 2002. Life-span Development : Perkembangan Masa Hidup. Edisi 5 jilid 2, Jakarta : Erlangga

Hurlock, Elizabeth.B, Psikologi Perkembangan: Suatu pendekatan sepanjang rentang kehidupan (edisi kelima), (Jakarta: Erlangga,1993)

Hurlock, Elizabeth. B., A Life-Span Approach, (Jakarta: Erlangga, 1980) 
Papalia, D. E., Olds, S. W., \& Feldman, R. D. (2008). Human development (Psikologi perkembangan edisi kesembilan). Jakarta: Kencana.

Suwarni Linda, Dinas Kesehatan Kota Pontianak Provinsi Kalimantan Barat . (2009) Monitoring Parental dan Perilaku Teman Sebaya Terhadap Perilaku Seksual Remaja SMA Di Kota Pontianak. Jurnal Promosi Kesehatan Indonesia Universitas Diponogoro

Suwarni Linda, Selviana Selviana. (2015). Inisiasi Seks Pranikah Remaja dan Faktor yang Mempengaruhi. Jurnal Kesehatan Masyarakat Universitas Negeri Semarang.

Peraturan Pemerintah Republik Indonesia Nomor 61 Tahun 2014 tentang Kesehatan Reproduksi

Pedoman Standart Nasional Pelayanan Kesehatan Peduli Remaja (PKPR) Kementrian Kesehatan RI 2014 